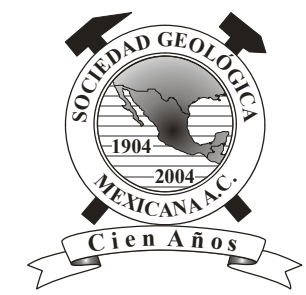

\title{
Remote sensing detection of potential sites in a prehispanic domestic agricultural terrace system in cerro San Lucas, Teotihuacan, Mexico
}

\author{
Julia Pérez-Pérez, ${ }^{1, *}$ Emily McClung de Tapia ${ }^{2}$, Luis Barba-Pingarrón ${ }^{3}$, \\ Jorge E. Gama-Castro ${ }^{4}$, Armando Peralta-Higuera ${ }^{5}$ \\ ${ }^{1}$ Posgrado en Antropología, Instituto de Investigaciones Antropológicas, Facultad de Filosofía y Letras, Universidad Nacional \\ Autónoma de México, Ciudad Universitaria 04510, México, D. F. \\ ${ }^{2}$ Laboratorio de Paleobotánica y Paleoambiente, Instituto de Investigaciones Antropológicas, Universidad Nacional Autónoma de \\ México, Ciudad Universitaria 04510, México, D.F. \\ ${ }^{3}$ Laboratorio de Prospección Arqueológica, Instituto de Investigaciones Antropológicas, Universidad Nacional Autónoma de México, \\ Ciudad Universitaria 04510, México, D. F. \\ ${ }^{4}$ Departamento de Edafología, Instituto de Geología, Universidad Nacional Autónoma de México, Ciudad Universitaria 04510 , \\ México, D.F. \\ ${ }^{5}$ Laboratorio de Fotogrametría y Percepción Remota, Instituto de Geografía, Universidad Nacional Autónoma de México, Ciudad \\ Universitaria 04510, México, D.F. \\ *julia_perezperez@hotmail.com
}

\begin{abstract}
Domestic agricultural terrace systems located in the basin of Mexico were the basis of prehispanic economic specialization and also the most widespread form of intensive cultivation in piedmont areas. This paper focuses on the remote sensing detection and field testing of potential scenarios to recover evidence of these prehispanic features. The testing area of this article is located in the piedmont of cerro San Lucas, Teotihuacan Valley, Mexico. The site was selected after consulting historical and archaeological documents, followed by aerial prospection. In addition, the interpretation of aerial digital images and the application of specific software for automated image analyses provided a unique set of tools for generating spatial predictions about the prehispanic household distribution at cerro San Lucas. During terrestrial surveys we corroborated that the detection quality of predicted archaeological sites by means of photointerpretation and automated image analyses was acceptable, but insufficient to locate archaeological sites. The field reconnaissance was followed by a program of geophysical survey combining three different methods: magnetic gradient, ground-penetrating radar and electrical resistivity. Based on the geophysical data results one sample site was excavated mainly to test the evidence previously collected. The cumulative results were invaluable in order to obtain: (1) a remote localization of some potential domestic agricultural spaces, (2) the field identification of a Late Postclassic aztec household unit (1490 B.P.), (3) relevant information about the ecological and archaeological context and (4) a basis for an accurate site selection conducive to extensive excavation.
\end{abstract}

Keywords: Remote sensing; aerial survey; automated image analyses; archaeological field reconnaissance; magnetic; groundpenetrating radar; resistivity; archaeological excavation; domestic agricultural terrace.

\section{Resumen}

Los sistemas agricolas domésticos en terraza localizados en la cuenca de México fueron la base de la especialización económica prehispánica así como la forma más extensa del cultivo intensivo en las áreas de piedemonte. El presente trabajo se enfoca en la detección de escenarios potenciales para recuperar la evidencia de esos rasgos prehispánicos, mediante técnicas de percepción remota y pruebas de campo. El área de interés de este artículo está situada en el piedemonte del cerro San Lucas, Valle de Teotihuacan, 
México. El sitio fue seleccionado después de consultar documentos históricos y arqueológicos, seguidos por una prospección aérea. Además, la interpretación de imágenes aéreas digitales y la aplicación de un "software" especifico para el análisis automatizado de imágenes, proporcionaron una serie de herramientas para generar predicciones espaciales sobre la distribución de habitaciones prehispánicas en el cerro San Lucas. Durante los recorridos de superficie corroboramos que la calidad de la detección de sitios arqueológicos pronosticados por medio de la interpretación de imágenes y del análisis automatizado de imágenes fue aceptable, pero insuficiente para la localización especifica del sitio arqueológico. El reconocimiento del campo fue seguido por un programa de reconocimiento geofísico que combina tres métodos diferentes: gradiente magnético, radar de penetración terrestre y resistencia eléctrica. De acuerdo con los resultados geofísicos, el sitio-muestra fue excavado principalmente para probar los datos previamente obtenidos. Los resultados acumulados fueron invaluables para obtener: (1) una localización remota de algunos espacios potenciales agrícolas domésticos, (2) la identificación de campo de una unidad habitacional azteca del periodo Postclásico Tardio (1490 d.C.), (3) información relevante sobre el contexto ecológico y arqueológico y (4) la base para una selección exacta del sitio dirigida a la realización de una excavación extensiva.

Palabras clave: percepción remota, reconocimiento aéreo, análisis automatizado de imagen, reconocimiento arqueológico, gradiente magnético, radar de penetración terrestre, resistividad eléctrica, excavación arqueológica, terraza agrícola doméstica.

\section{Introduction}

Throughout the basin of Mexico, traces of relict prehispanic agricultural field systems can be found, for example: domestic agriculture terraces, raised fields (chinampas), and irrigation canals that were once part of highly productive landscapes (Rojas-Rabiela, 1988; Nichols, 1987). The archaeological record of these cultural landscapes provides important multi-temporal insights into issues such as cultural anthropology, past human ecology and applied earth sciences (Erickson, 1992). Thus, the reconnaissance and characterization of these subsistence agriculture patterns provide important multi-temporal insights into issues such as: $(i)$ agricultural sustainability (Nichols and Frederick, 1993); (ii) indigenous knowledge systems (Evans, 1980, 1990); (iii) human- vs. naturalinduced environmental impact, (Mc Clung et al., 2003; Gama-Castro et al., 2004, 2005); (iv) geomorphological and anthropic-pedological processes that influence soil development (Rivera-Uria et al., 2007) and (v) climatic and biodiversity changes (Solleiro-Rebolledo et al., 2006).

Unfortunately, in Mexico, many of these physical remains of past human activity are still found only by accident, while other relevant sites stay undiscovered or are gradually destroyed by multicausal agents. Therefore, we consider that there is an urgent need to develop nondestructive approaches for their remote identification and synoptic understanding of their biosphere, geosphere, and archaeosphere context.

With these considerations in mind, the aim of this study is: ( $i$ ) to detect the presence of prehispanic domestic agricultural terrace systems by means of remote sensing techniques; and (ii) to select the probable site for excavation by means of geophysical methods and field archaeological evaluation.

A significant archaeological test site was selected in the Teotihuacan valley, Mexico and its investigation started in november 2004. The test area, called cerro San Lucas (CSL), was selected based on consultation of historical and archaeological archives, aerial reconnaissance, aerial image interpretation, and automated image analyses in the laboratory.

According to Evans (1992), the chosen site is located in an area that represents one of the best examples of intensive Aztec terrace agriculture in marginal lands that have survived recent, extensive leveling by machinery for modern-day cultivation.

The selected site for archaeological excavation was included in a comprehensive program of geophysical survey combining three different methods: magnetic gradient, ground-penetrating radar, and electrical resistivity. The accuracy of resulting information was tested by means of an archaeological field evaluation.

Our results showed that both, remote sensing and field geophysical reconnaissance data, provided valuable indications to detect household/agricultural spaces, in addition to specific information concerning the extension, relative depth, and form of the buried archaeological features, contributing to the accurate and precise selection of a site amenable to archaeological excavation. In addition, we also obtained information about three-dimensional soil terrace properties and potential past land use and soil degradation during the last 500 years.

\section{An overview of cerro San Lucas (CSL)}

CSL is located in the physiographic province of the Transmexican Volcanic Belt, located approximately 65 $\mathrm{km}$ northeast of Mexico City, in the eastern sector of the Teotihuacan valley, Mexico (Figure 1). The main environmental factors that characterize the testing area are summarized in Table 1.

Based on the scholarly historical data and archaeological 


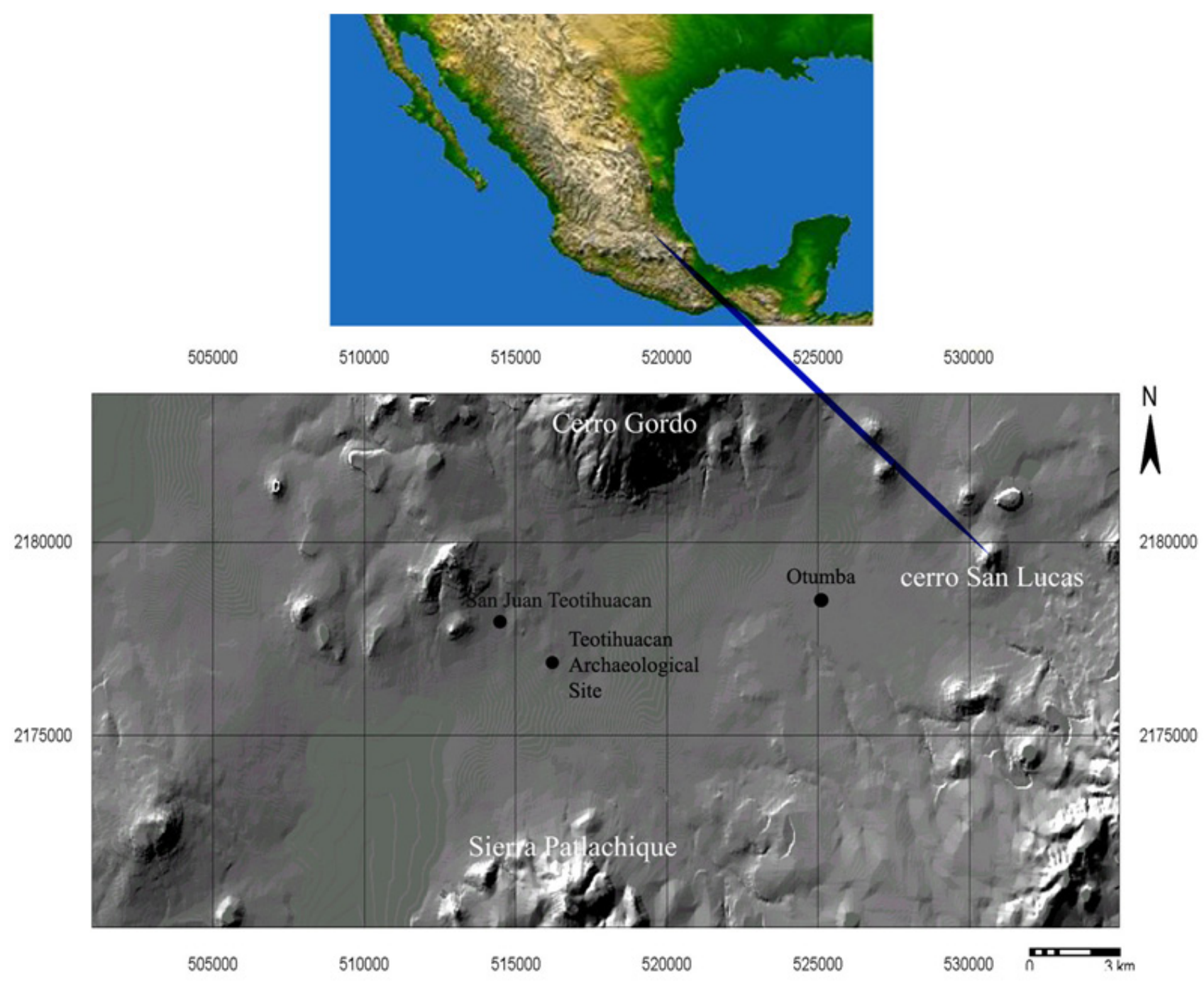

Figure 1. Localization of Cerro San Lucas study area.

research on CSL, there is enough evidence to support that this site constituted part of the complex structure of an aztec terrace village called Cihuatecpan by other archaeologists (Sanders, 1965; Evans, 1980, 1986, 1988, 1992; Nichols, 1987; Córdova and Vázquez, 1991). According to Evans (1988), Cihuatecpan was a village of some 200 houses and terraces scattered around the south slope of CSL, established sometime after AD 1000.

The Cihuatecpan terrace system encompassed two different kinds of horticultural strategies. First, grains would have been grown on the flat areas and maguey (Agave) or nopal (Opuntia) on the embankments (metepantli [from the Nahuatl: metl, maguey and pantli, line or row]), and this would constitute milpa farming. Second, the terrace surfaces close to the houses would be used for kitchen gardens (calmilli), where tomatoes and other vegetables, as well as herbs, flowers, and a small amount of corn would have been grown for household use.

Excavations at Cihuatecpan revealed evidence of several specialized craft activities, in particular obsidian tool production and maguey processing.

\section{Description}

Research was carried out in the following steps, based on the methodology proposed by Barba $(1984,1994)$. The methods and materials employed are briefly summarized below.

\subsection{Aerial image acquisition}

To be able to obtain qualitative archaeological imagery, low-altitude prospection flights over the study area were carried with an aerostatic balloon (100 m above ground) (Figure 2). In this instance black and white vertical and oblique images and near-infrared images were obtained using various high-resolution digital cameras: Nikon D2x, D70, Kodak DCS 14n and Canon EOS 300D (Prado-Molina et al., 2006). 
Table 1. Diagnostic environmental factors present in the Cerro San Lucas study area.

\begin{tabular}{ll}
\hline $\begin{array}{l}\text { Geographic } \\
\text { location of test } \\
\text { area: }\end{array}$ & $19^{\circ} 42^{\prime} 43^{\prime \prime} \mathrm{N} 98^{\circ} 42^{\prime} 31^{\prime \prime} \mathrm{W}$ \\
\hline Lithology & $\begin{array}{l}\text { Dacite buried lavas interdigitated with } \\
\text { several reworked deposits of pyroclasts, } \\
\text { and sediments erode and transported } \\
\text { from and back slope of volcano. } \\
\text { (Mooser, 1968) }\end{array}$ \\
& $\begin{array}{l}\text { Surface morphometry is variable, for } \\
\text { instance the slopes have gradients that }\end{array}$ \\
Relief & $\begin{array}{l}\text { range from }<3^{\circ} \text { (piedmont) to 24 } \\
\text { (pediment shoulder) (Pérez-Pérez, 2003) }\end{array}$ \\
Climate & $\begin{array}{l}\text { Semiarid climate. Mean annual } \\
\text { precipitation: } 500 \text { mm. Mean annual } \\
\text { temperature: } 18^{\circ} \mathrm{C} \text { (García, 1973) }\end{array}$ \\
& $\begin{array}{l}\text { Plant communities characteristic of the } \\
\text { study site include xerophytic vegetation, } \\
\text { shaped by an overall deficit of available } \\
\text { soil moisture (arid moisture regimen). } \\
\text { (Castilla-Hernández and Tejero-Diez, }\end{array}$ \\
Land cover/ \\
1983) \\
vegetation \\
$\begin{array}{l}\text { Maguey and nopal cultivation, as well as } \\
\text { marginal rainfed field cultivars. }\end{array}$ \\
\hline Land use
\end{tabular}

Soils were classified according to the World Reference Base for Soil Resources (WRB, 2006).

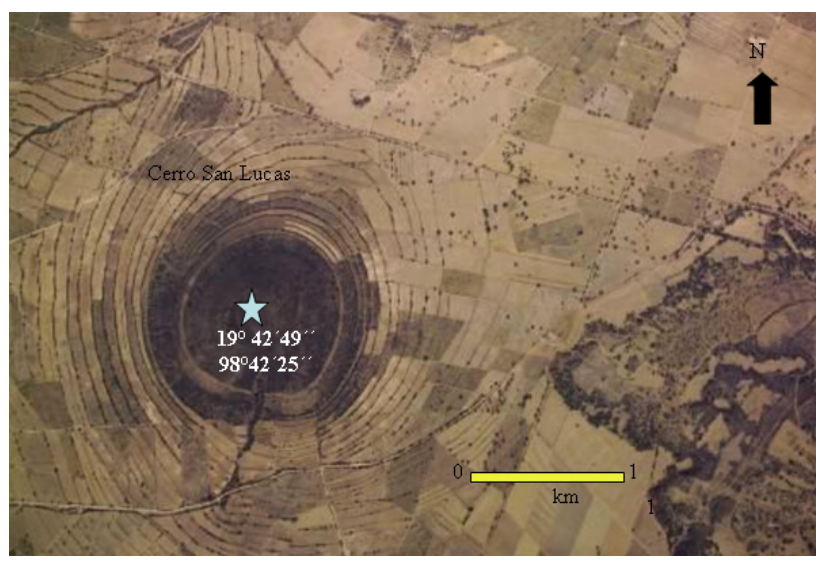

Figure 2. Vertical image of Cerro San Lucas, visible format using $70 \mathrm{~cm}$ resolution.

\subsection{Aerial image interpretation}

In accordance with the methodology utilized by Congalton (1991) and Bewley et al. (1998), aerial images of the Teotihuacan valley were scanned with a stereoscope in order to develop a synoptic view of the biosphere and potential archaeosphere representative of the CSL area. As was mentioned before, the selection of the testing area (CSL) was performed on the basis of previously generated environmental data, historical documents, and archaeological research reports.

\subsection{Automated image analyses}

The analyses of the CSL scene, including image enhancement and optical contrast-stretching were undertaken by means of the software Image-Pro Plus (1999) version 4.1. The image enhancement of the study area was made using manipulated color data (RGB model), background subtraction, spatial geometric operations and contrast filters (Fast Fourier Transforms). In addition, this software also facilitated the registration of spectral data from the image in graphic form (histogram).

\subsection{Surface survey}

Based on the procedures outlined by Ammerman (1981) and Aldenderfer and Hale-Pierce (1984) field exploratory survey was planned to evaluate the degree to which airimages scenes offered realistic representations and their effectiveness for archaeological site selection. This survey involved combing the test area on foot as well as the use of mechanized transport, to recognize photo-spectral signatures (e.g. soil marks) and artifacts visible on the surface. The whole site was surveyed using a Geographic Position System (GPS), collecting detailed morphological information. The systematic collection of archaeological materials in the site was undertaken based on a $60 \times 60$ $\mathrm{m}$ grid with squares measuring $1 \mathrm{~m}$ each side (Figure 3). Surface survey also included micro-excavation techniques such as augers and corers.

\subsection{Geophysical techniques}

Three geophysical techniques were employed to determine the presence of structures: magnetic gradient; ground penetrating radar and electrical resistivity. In addition, a topographic map was created for the geophysical prospection covering a surface of $20 \times 80 \mathrm{~m}$ taking readings at the corners of each square.

\subsubsection{Magnetic gradient}

The magnetic survey was carried out on the ploughed surface immediately following completion of the fieldwalking survey. The selected area was surveyed using a Geoscan FM36 fluxgate gradiometer, and the land was sampled at intervals of $0.25 \mathrm{~m}$ in transects with direction NE $26^{\circ}$ and a distance among them of $1 \mathrm{~m}$, resulting in a total of 6400 readings of magnetic gradient (Figure 4).

\subsubsection{Ground Penetrating radar (GPR)}

This aspect of the geophysical survey was undertaken in march 2005, using a ground penetrating radar GSSI, model SIR-2 equipped with a $400 \mathrm{MHz}$ monostatic antenna; this device was used as a complementary method to the magnetic 
gradient. Forty-two lines of verification were established in the central grid where the important magnetic anomalies appeared, generating $840 \mathrm{~m}$ of continuous profiles (Figure $5)$.

\subsubsection{Electrical resistivity}

In order to establish a correlation between the magnetic gradient data and the GPR, the electrical resistivity was measured in the central grid where the profiles with GPR were undertaken. The data were collected with an instrument manufactured by M.A.E. with 32 intelligent electrodes; they respectively rose to 20 electrical lines in a dipole-dipole array at sampling intervals of $0.5 \mathrm{~m}$ and $1 \mathrm{~m}$. A total of 12800 datapoint readings were obtained (Figure 6).

\subsubsection{Excavation}

In march and may of 2005, one sample area was excavated to verify the geophysical results, testing the features interpreted as a building within the innermost enclosure and examining a rectangular feature hypothesized to be a domestic structure. An area of $14 \times 20$ m was selected for excavation, based on the data obtained from the geophysical methods.

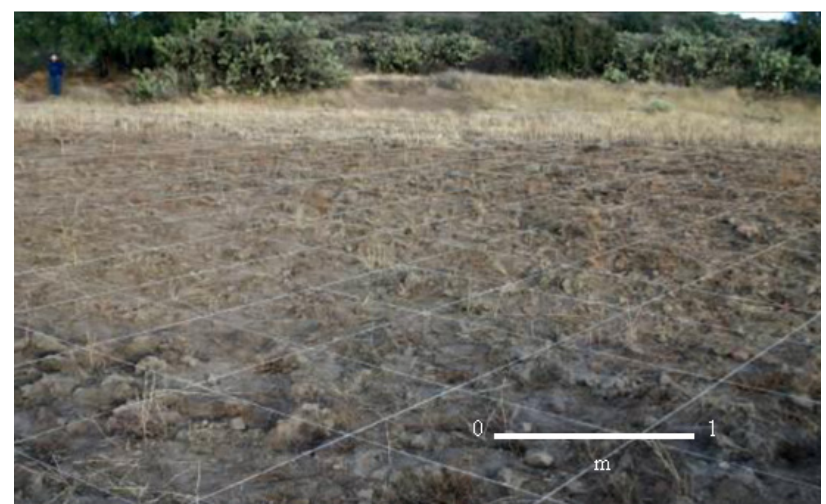

Figure. 3. Positioning of the surface grid for collection of archaeological materials, topographical survey and chemical study.

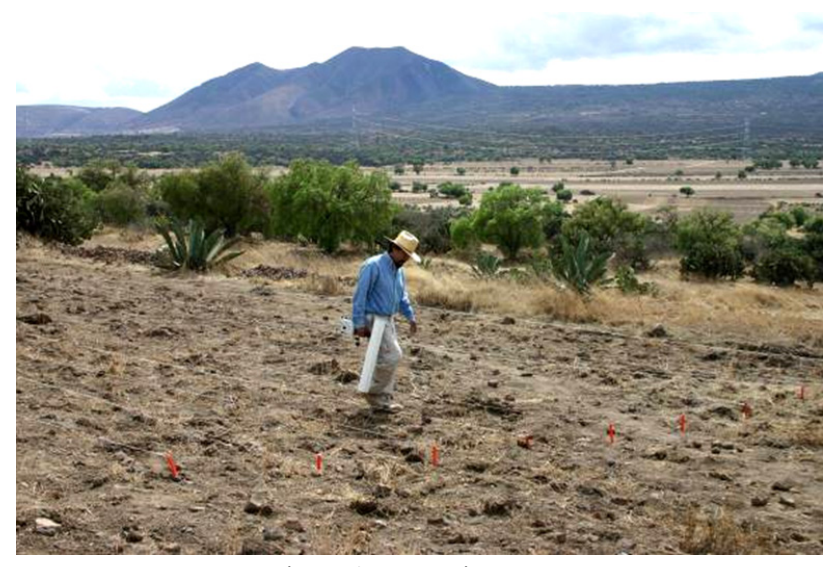

Figure 4. Magnetic survey.

\section{Results}

\subsection{Remote sensing}

Interpretation of aerial images of the study area allowed us to recognize fundamental environmental elements in the CSL image dissection, such as: $(i)$ morphometry and morphological characteristics of the landscape; (ii) spatial frequency and contrast variations in the terrain's relief; (iii) lithology (iii) land use (iv) erosion (type and intensity); (v) types of soils to be expected and (vi) additional features, for instance: terraces, drainageways, roads and buildings (Table 1)

The software utilized for the image analyses of the CSL scene, allowed a better appreciation of fine spectral details within the site context. Thus, it was possible to recognize and classify based on the particular image histogram, the presence of soil marks characterized by differences in soil color related to buried archaeological features, shadow marks caused by the differences in height on the ground produced by archaeological remains, and a pattern of regular geometric shapes and boundaries (all were stone

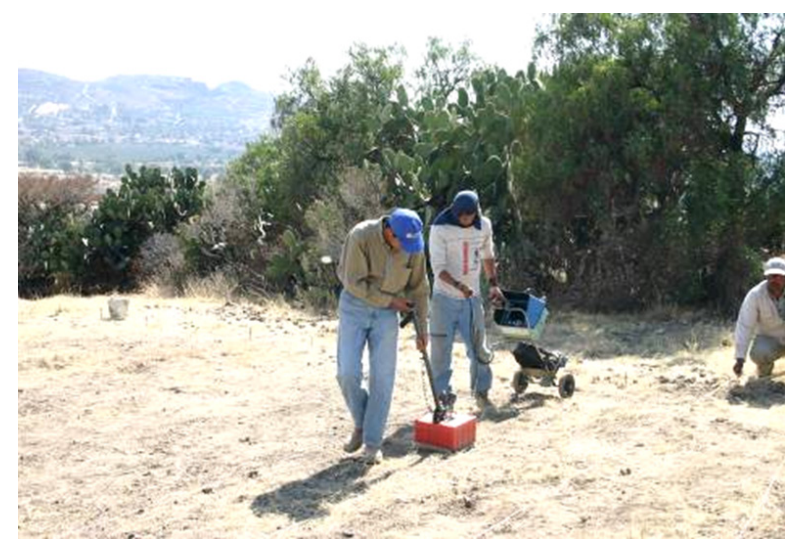

Figure 5. Ground penetrating radar survey.

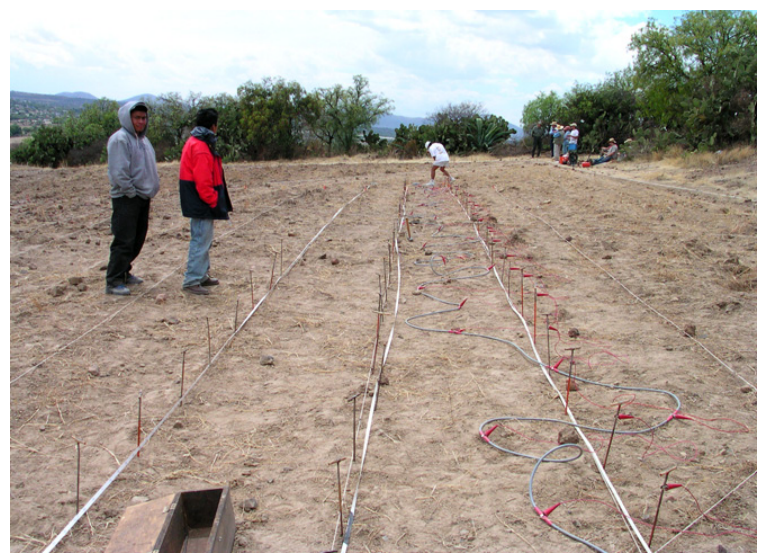

Figure 6. Data acquisition with the electrical equipment. 
walls), anomalous to the natural ecotype of the study area (Figure 7). These spectral anomalies were associated with changes in vegetation status, and also with electromagmetic and dielectric properties of the soil. According to Curtis et al. (1995) and Hendrickx et al. (2001), both properties are characteristic of particular soils such as texture, bulk density, mineralogy, organic matter content, and frequency, but especially water content.

During subsequent field survey, we corroborated the association of these spectral anomalies with the presence of cultural features, including terrace structures and buried remains of a rural domestic unit. In addition, we also detected that many kinds of surface materials, and buried archaeological remains could be distinguished from each other by differences in their reflectance and distinctive spectral signatures.

\subsection{Geophysical survey}

The magnetic gradient data revealed two anomalies in the central grids. The first one is characterized by magnetization by induction and the second one appears to be produced by the concentration of dipoles resulting from the two poles found on every single stone that display the form of the altered structure. In grid 2, two rectangular structures are registered, divided by a central alignment. The southwestern structure shows a noisier magnetic pattern produced by the large number of stones on the surface, masking the peripheral walls of the room, because the surface has been considerably altered, thus destroying part of the structure. The northeast structure shows the most clear magnetic pattern, delimiting the wall that divides both rooms as well as the peripheral walls (Figure 8).

The verifications with georadar in the center of the

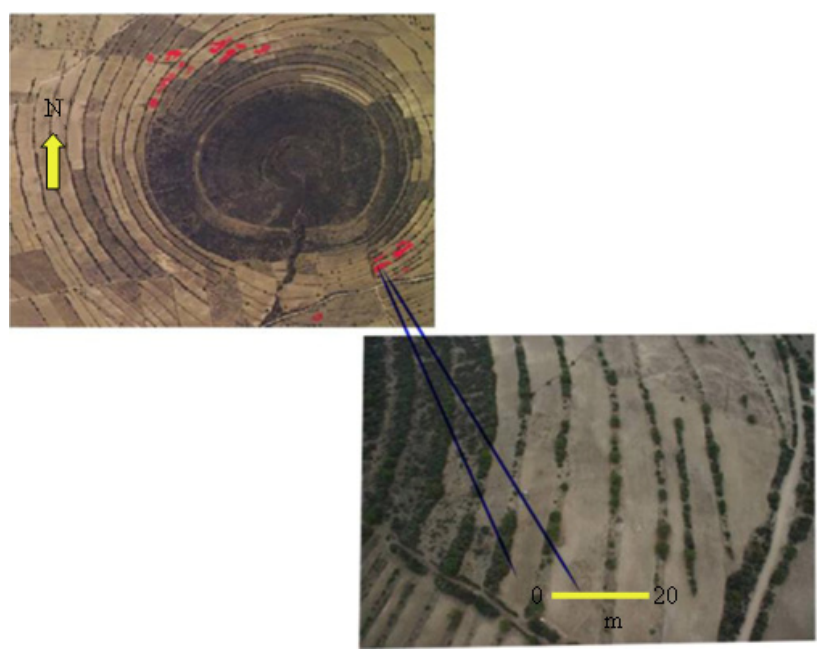

Figure 7. Image analysis with the software Image-Pro Plus 4.1. Spectral properties of a series of geometric features distributed over the terraces are marked in red. The variables considered for the analysis include form, size, tone, color and texture. structure were carried out to obtain the dimensions and depth of the magnetic pattern (Figure 9). Radargrams of lines 13 and 15 show superficial reflections of average amplitude between $0.2 \mathrm{~m}$ and $0.3 \mathrm{~m}$ of depth produced by the stone walls, as well as reflections produced by superficial material that is related to material removed by the plow. A slight change in the dielectric characteristics of tepetate is registered at a depth of $1.2 \mathrm{~m}$ produced by a humidity change and greater homogeneity in composition, indicated by the diminution in the amplitude of the reflections (Figure 10).

In order to complement the results of the magnetic gradient and penetration radar, the electrical data indicated an increase in the values of resistivity in the southwestern zone related to the stone structure, and disturbed materials. The walls of the structure were registered with low resolution due mainly to the sampling interval of $0.5 \mathrm{~m}$ used in the survey, showing limited contrast between the stone walls and tepetate, most notably in the southeast wall where electrically there is no difference with tepetate (Figure 11).

\subsection{Excavation of the anomaly}

An area of $14 \times 20 \mathrm{~m}$ was selected for excavation, based on the data obtained from the geophysical methods (Figure 12). A rectangular domestic structure of approximately 13 x $7 \mathrm{~m}$ was uncovered (Figure 13). Based on the type and distribution of the archaeological materials, it comprised three rooms: a) a food preparation area, b) a storage area and c) a living area.

The domestic unit was built on a terrace designed for habitation. The terrace showed a succession of layers of soil of anthropic origin overlying tepetate (tuff) on which the foundations of the building were placed (Figure 14).

The ceramic materials recovered from both the surface and the excavation included four predominant forms: cajetes (bowls), ollas (pots), jarras (jars) and comales (griddles), indicating the domestic character of the structure. The presence of malacates (spindle whorls) and scrapers led us to infer economic activities related to maguey (Agave) processing, including scraping the pencas (leaves) and spinning the fiber obtained (McClung et al., 2005).

\section{Discussion}

In the search for prehispanic domestic spaces in the cerro San Lucas area, Teotihuacan valley, the application of prospecting techniques for the study of archaeological sites was successful and generated useful results for our research. The contrast between the physical properties of rock (geological substrate) and the stones used to build the walls of the housing structure allowed the detection of anomalies and the location of archaeological evidence.

Aerial images allowed a general recognition of the site and the selection of interesting areas, considering the light spots on the surface. In spite of the dispersion caused by 


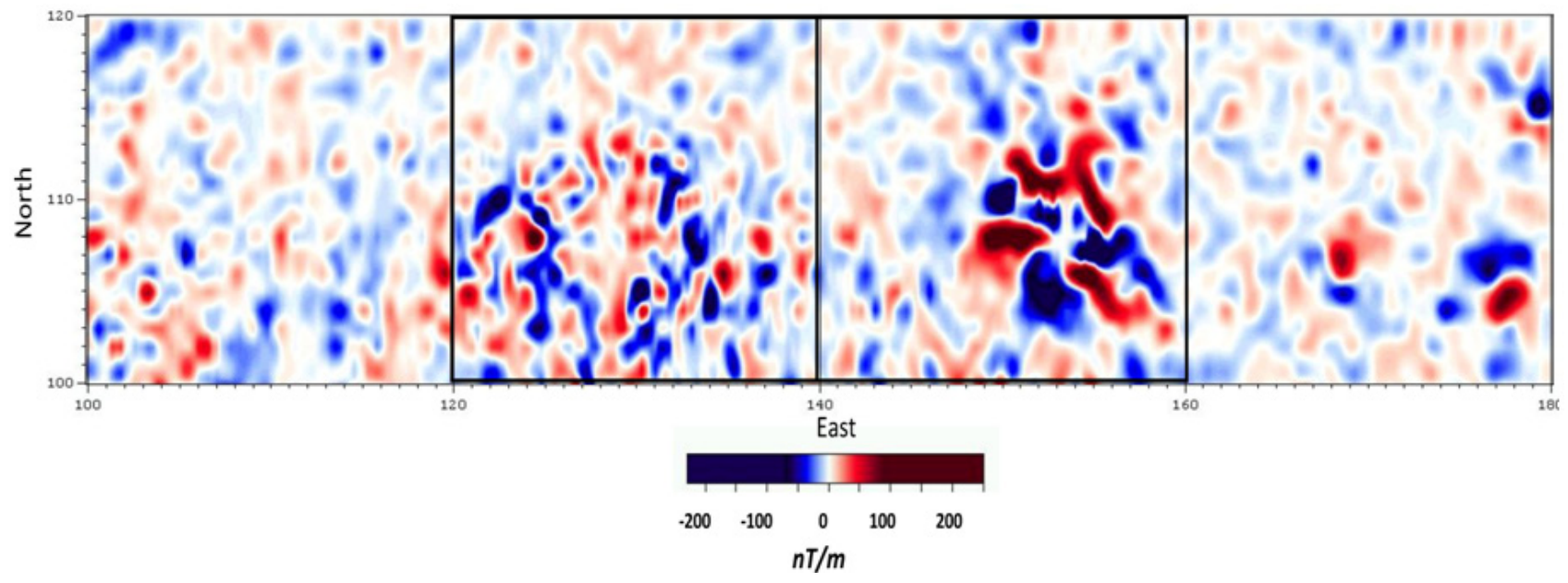

Figure 8. Anomalies detected with the gradiometer.

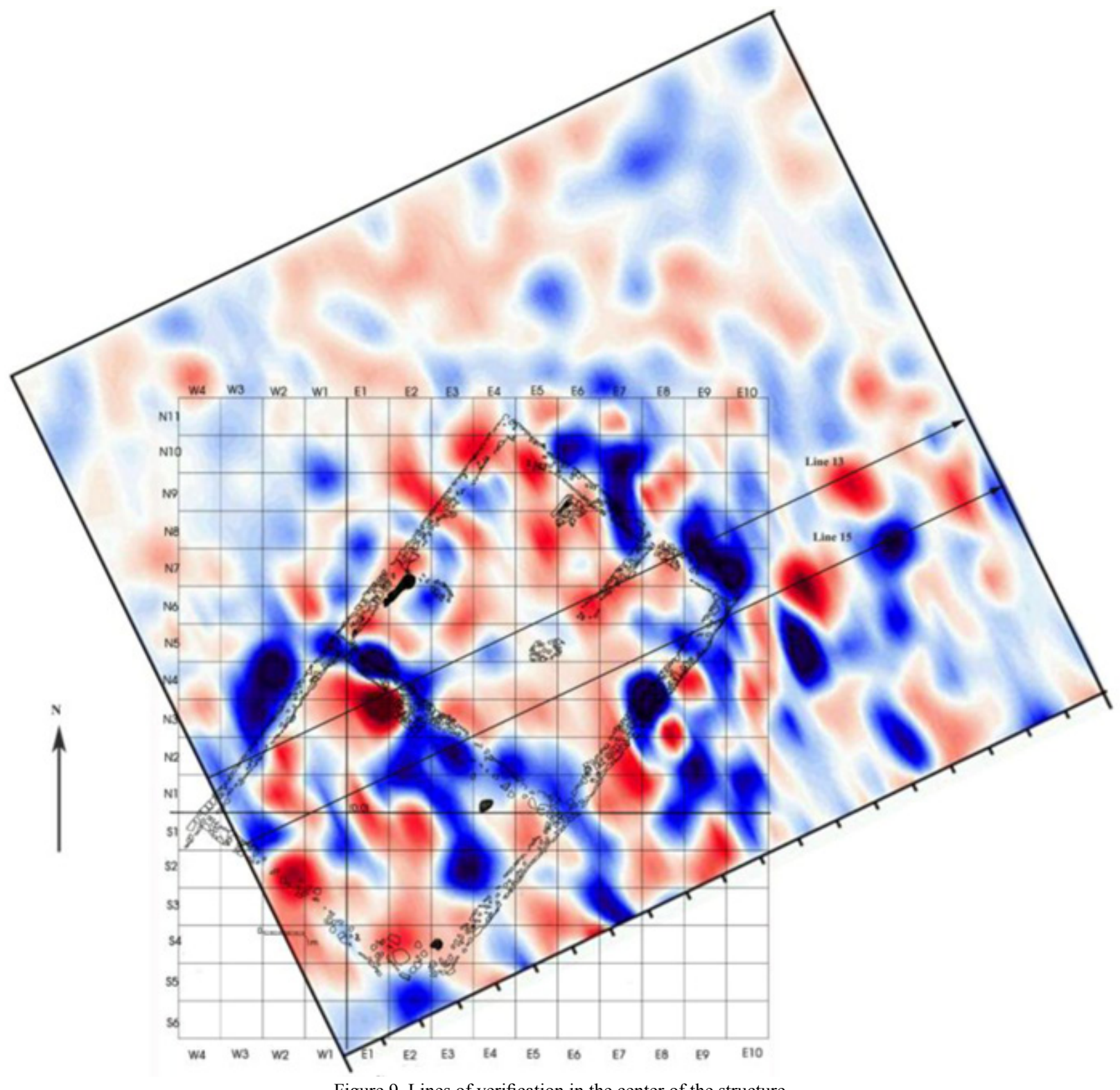

Figure 9. Lines of verification in the center of the structure. 

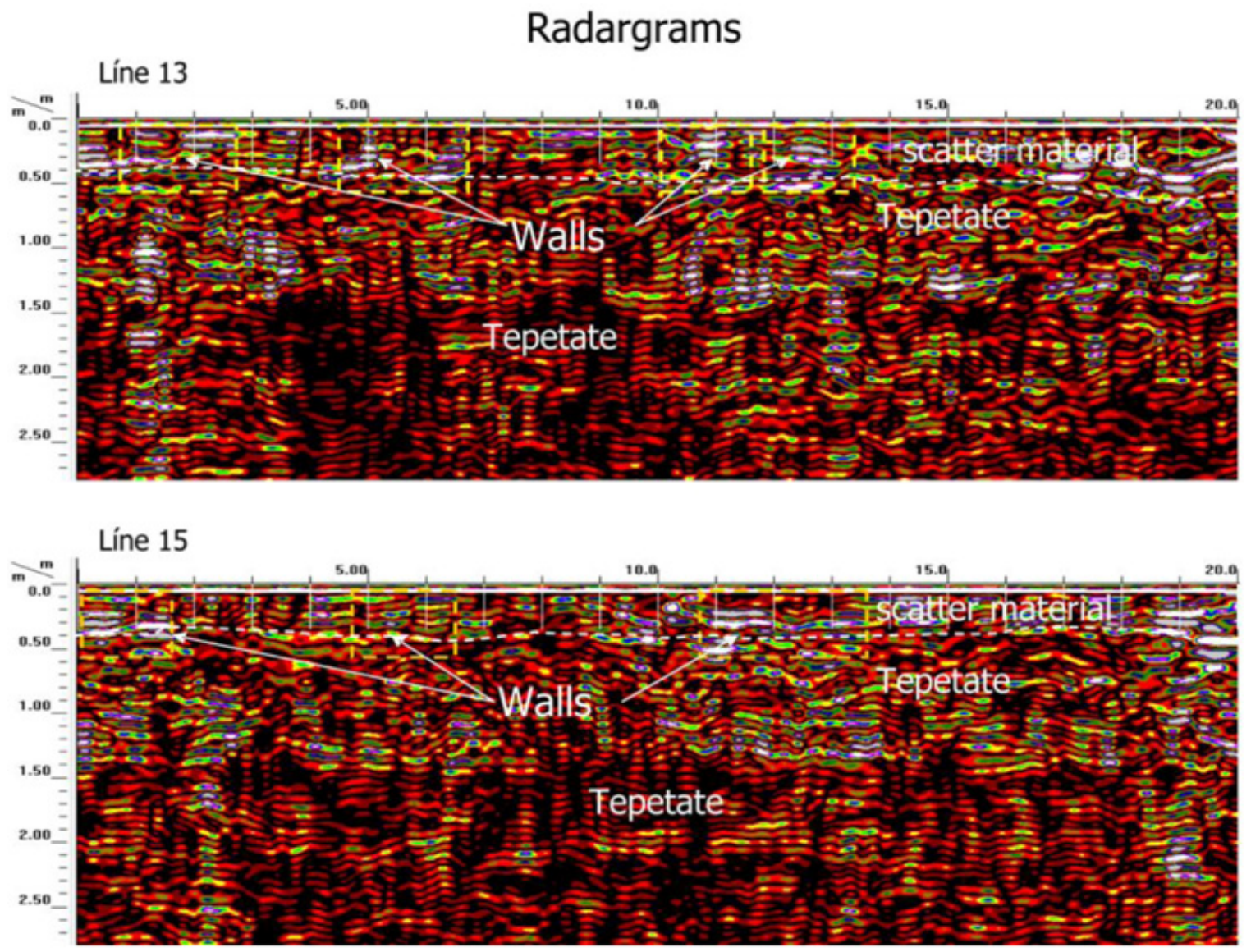

Figure 10. Lines 13 and 15 show the reflections of the stone walls in contrast with tepetate.

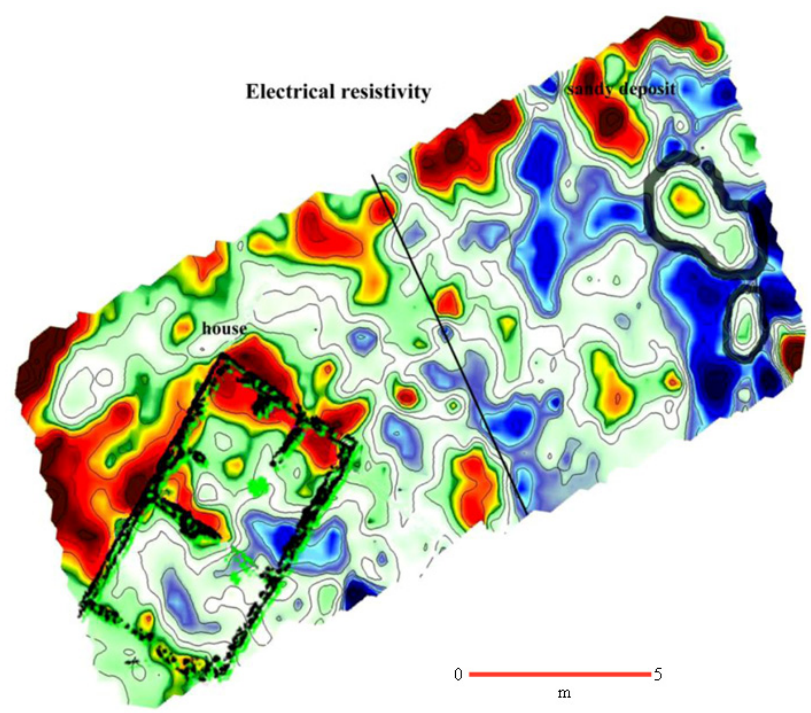

Figure 11. Electrical data show an increase in the values of resistivity in the SW sector of the house.

agricultural activities in recent years, the magnetic gradient was able to approximate the shape and dimensions of a domestic structure. The radar lines were able to determine the exact position of the walls and their depth. The electrical resistivity confirmed the presence of the walls on one side of the unit but was unable to recognize the opposite limit where they were most disturbed.

The geophysical survey conducted in the area of our interest allowed the identification of an anomaly associated with a quadrangular structure. Subsequent excavation of the anomaly area corroborated the existence of a dwelling unit consisting of three rooms where daily activities related to the survival of its occupants took place. On the other hand, the archaeological materials found on the surface and from the excavation of the structure, allowed us to infer predominantly economic activities such as scraping and extraction of fibers of maguey leaves and spinning by the prehispanic inhabitants of the domestic unit.

\section{Conclusions}

In this investigation the search for spaces destined for prehispanic agricultural and domestic activities in CSL benefited immensely from the application of an integrated methodological program. This combined prospecting method included the use of aerial reconnaissance flights and field archaeological surveys, together with remote sensing and automatic image analysis as well as geophysical 


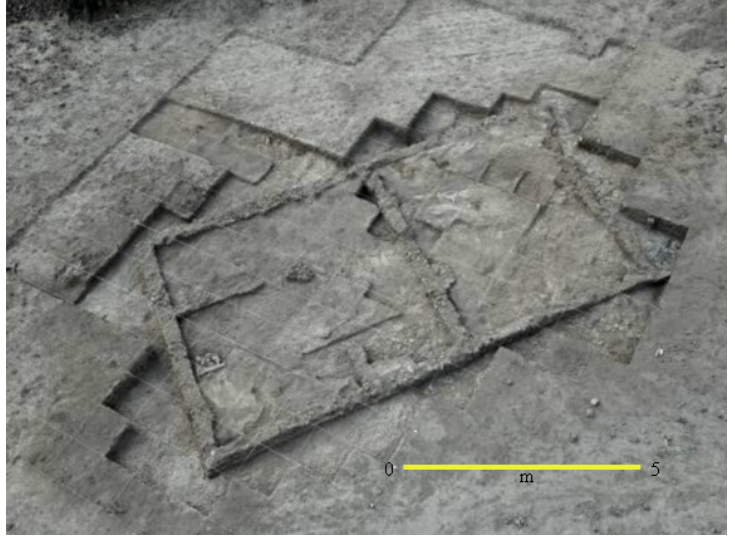

Figure 12. Area of excavation.

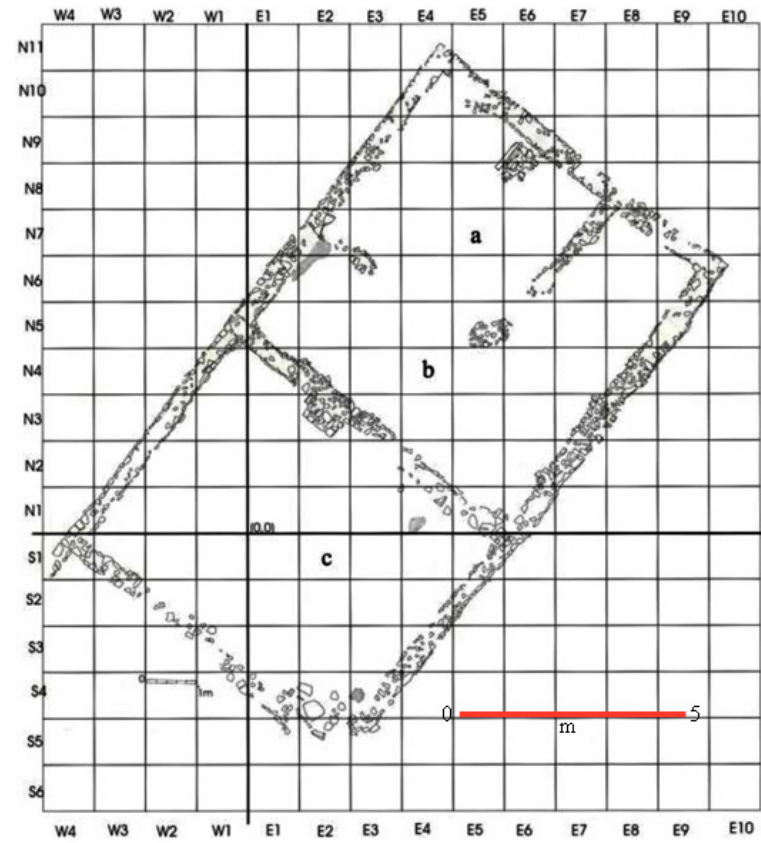

Figure 13. The domestic structure was comprised three rooms: a) food preparation area; b) storage area; and c) living area.

techniques and extensive excavation. The integration of this multimethod approach generated reliable and immediate information concerning the characteristics of the object of our study, permitting more efficient planning of time and available financial resources, thus contributing to a successful excavation.

The original methodological proposal (Barba, 1984, 1994) was improved by the introduction of new aerial image acquisition and processing. For instance: $(i)$ aerial survey was a useful tool for collecting regional information, selecting a potential study site, and acquiring suitable aerial images; (ii) the interpretation of high resolution aerial images facilitated the identification of surface features (anthropogenic marks) associated with past human activities; (iii) the automated analyses of the CSL sub-scenes, allowed us to recognize

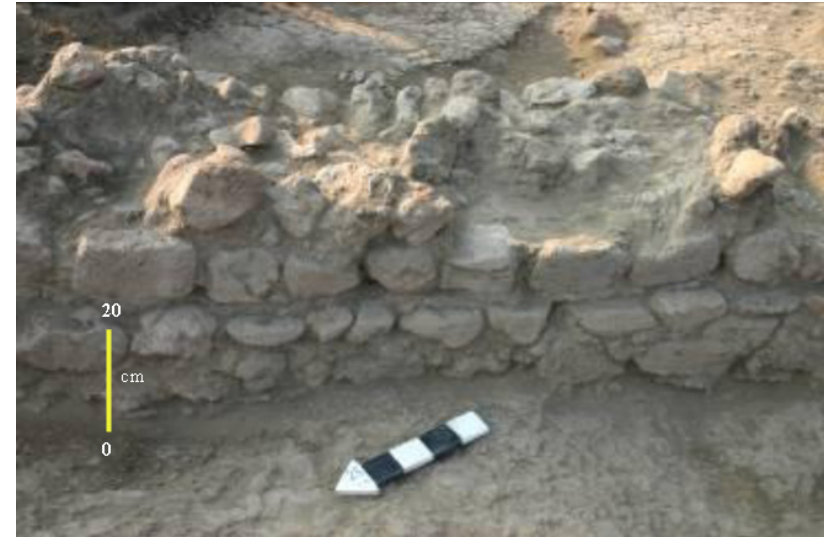

Figure 14. Walls of the house overlaying tepetate.

the spectral properties of probable household/agriculture systems and automatically to extrapolate this information to similar areas in the rest of the CSL scene; (iv) field archeological survey permitted us to effectively evaluate the degree of detectability of the predicted archaeological sites by means of image interpretation and automated image analyses; and ( $v$ ) geophysical survey, including gradiometry, magnetometry and ground penetrating radar was a basis for an accurate site selection appropriate for open-area archaeological excavation.

The archaeological excavation revealed the presence of a Late Postclassic Aztec household unit dated to approximately 1490 B.P. (Beta 213879) [Cal AD 1430 to 1520 (Cal BP 520 to 430) and Cal AD 1580 to 1630 (Cal $\mathrm{BP} 380$ to 320)] that comprised three rooms. The abundance of ceramic materials indicated the domestic character of the structure, in spite of the predominance of very shallow, rocky soils characterized by their severe limitations making them generally unsuitable for cultivation of annual crops. However, the frequent presence of malacates (spindle whorls) and scrapers recovered from the excavation and surrounding areas led us to infer long-term economic activities related to maguey (Agave) processing, including scraping the pencas (leaves) and spinning the fiber obtained.

These successful results lay the foundation for a long-term project designed to assess settlement patterns associated with the terraces of cerro San Lucas using remote sensing and limited excavation.

\section{Acknowledgements}

This research was funded through CONACYT (090220 APOY-COMPL-2008) to Jorge E. Gama Castro; CONACYT (190305-2004) to Julia Pérez Pérez, FAMSI (05028-2005) to Julia Pérez Pérez for financial support to the project from 2004 to 2008. We also thank the Coordinación de Estudios de Posgrado, Universidad Nacional Autónoma de México, for the support given during the research. The authors thank 
David Carballo for the valuable comments and suggestions to the original manuscript.

\section{References}

Aldenderfer, M.S., Hale-Pierce, C., 1984, The Small-Scale Archaeological Survey Revisited: American Archeology, 4, 4-5.

Ammerman, A.J., 1981, Surveys and Archaeological Research: Annual Review of Anthropology, 10, 63-88.

Barba, L., 1984, The Ordered Application of Geophysical, Chemical and Sedimentological Techniques for the Study of Archaeological Sites: The Case of San José Ixtapa, México: Athens, Georgia, University of Georgia, master's thesis.

Barba, L., 1994, A Methodology for the Study of Buried Archaeological Sites, in Scott, D.A., Meyers P. (eds.), Archaeometry for PreColumbian Sites and Artifacts, Proceedings of a Symposium, University of California at Los Angeles, Institute of Archaeology, The Getty Conservation Institute: Los Angeles, California, 353-366.

Bewley, R., Donoghuem D., Gaffney, V., van Leusen, M., Wise, A., 1998, Archiving Aerial Photography and Remote Sensing Data: A Guide to Good Practice. Arts and Humanities Data Service Guides to Good Practice. Arts and Humanities Data Service. http://ads.ahds.ac.uk/ project/goodguides/apandrs [Consulta: 15 mayo 2010]

Castilla-Hernández, M., Tejero-Diez, J.D., 1983, Estudio florístico del Cerro Gordo (Próximo a San Juan Teotihuacan) y regiones aledañas: México, Universidad Nacional Autónoma de México, Escuela Nacional de Estudios Profesionales-Iztacala, tesis de licenciatura, $127 \mathrm{p}$.

Congalton, R., 1991, A review of assessing the accuracy of classifications of remotely sensed data: Remote Sensing of Environment, 37, 35-46.

Córdova, C.E., Vázquez, A., 1991, Tipología para Terrazas de Cultivo en el Contexto de los Sistemas Agrícolas Tradicionales de Mesoamerica: Tópicos de Investigación y Posgrado, 2, 13-24

Curtis, J.O., Weiss, C.A, Everett, J.B., 1995, Effect of soil composition on complex dielectric properties: Waterways Experiment Station, Vicksburg, Mississippi, United States of America Army Corps of Engineers, Technical Report, $59 \mathrm{p}$.

Erickson, C., 1992, Applied Archaeology and Rural Development: Archaeology's Potential Contribution to the Future: Journal of the Steward Anthropological Society, 20, 1-16.

Evans, S.T., 1980, A Settlement System Analysis of the Teotihuacan Region, Mexico. A.D. 1350-1520: Pennsylvania State University, University Microfilms, Ann Arbor, Ph.D. dissertation, 420 p.

Evans, S.T., 1986, Analysis of the Surface Sample Ceramics, in Sanders, W.T (ed.), The Teotihuacan Valley Projects: Final Report, vol. 4, University Park, Pennsylvania State University, 283-366.

Evans, S.T., 1988, Excavations at Cihuatecpan. An Aztec village in the Teotihuacan Valley: Nashville, Tennessee, United States of America, Vanderbilt University Publications in Anthropology, Department of Anthropology.

Evans, S.T., 1990, The productivity of maguey terrace agriculture in central Mexico during the Aztec Period: Latin American Antiquity $1(2), 117-132$.

Evans, S.T., 1992, The productivity of maguey terrace agriculture, in Killion, T.W. (ed.), Central Mexico during the Aztec period, in Gardens of Prehistoy. The Archaeology of Settlemente agriculture in Greater Mesoamerica: Tuscaloosa, Alabama, University of Alabama Press, 93-115.

Gama-Castro, J.E., Solleiro-Rebolledo, E., McClung, E., Villalpando, J.L., Sedov, S., Jasso-Castañeda, C., Palacios-Mayorga, S. 2004, Contribuciones de la Ciencia del Suelo a la Investigación Arqueológica: El caso de Teotihuacan: Revista Terra, 23, 1-12.

Gama-Castro, J.E., McClung de Tapia, E., Solleiro-Rebolledo, E., Ibarra, E., Sedov, S., Jasso-Castañeda, C., Vallejo-Gómez, E., Pi-Puig, T., Cabadas-Báez, H., 2005, Incorporation of ethnopedological knowledge in the study of soils in the Teotihuacan valley, Mexico: Eurasian Soil Science, 38, 95-98.
García, E., 1981, Modificaciones al Sistema de Clasificación Climática de Köppen (para adaptarlo a las condiciones de la República Mexicana). Offset Larios, México.

Hendrickx, J.M., Borchers, B., Woolslayer, J., Dekker, L.W., Ritsema, C., Paton, S., 2001, Spatial variability of dielectric properties in field soils, in Dubey, A.C., Harvey, J.F., Broach \& George V. (eds), Detection and remediation technologies for mines and minelike Targets VI, A. C. SPIE: Orlando, Proceedings of the SPIE 4394, 398-408.

Image-Pro Plus version 4.1. for Windows. 1999, The Proven Solution for Image Analysis: Silver Spring, Maryland, United States of America: http://www.mediacy.com sales@mediacy.com

McClung, E., Solleiro-Rebolledo, E., Gama-Castro, J.E., Villalpando, J.L., Sedov, S., 2003, Paleosols in the Teotihuacan Valley, México: evidence for paleoenvironment and human impact: Revista Mexicana de Ciencias Geológicas, 20, 270-282.

McClung, E., Pérez-Pérez, J., Barba, P.L., Ortíz, A., Blancas, J., Conte, G., Gama, J., Solleiro, E.,, Sedov, S., Peralta, A., 2005, Informe parcial de la primera y segunda etapa de investigación del Proyecto Agricultura en terrazas en el cerro San Lucas, Valle de Teotihuacan, al Consejo de Arqueología, INAH: México, Instituto de Investigaciones Antropológicas, UNAM.

Mooser, F., 1968, Geología, naturaleza y desarrollo del Valle de Teotihuacan, in Lorenzo, J. L (ed.), Materiales para la Arqueología de Teotihuacan XVII, INAH: México, 31-38.

Nichols, D., 1987, Risk and Agricultural Intensification during the Formative Period in the Northern Basin of Mexico: American Anthropologist, 89, 596-616.

Nichols, D., Frederick, C.D., 1993, Irrigation canals and chinamapas: The development of hydraulic agriculture in the northern Basin of Mexico, in Isaac, B.L., and Scarborough V., (eds.), Water Management, Research in Economic Anthropology Supplement 7, Greenwich, Connecticut: Jai Press, 123-150.

Pérez-Pérez, J., 2003, Agricultura en Teotihuacán. Una forma de modificación al paisaje: Mexico, Facultad de Filosofía y Letras, Instituto de Investigaciones Antropológicas, UNAM, tesis de maestría, $140 \mathrm{p}$.

Prado-Molina, J., Peralta-Higuera, A., Palacio-Prieto, J.L., Sandoval, R., 2006, Airborne high-resolution digital imaging system: Journal of Applied Research and Technology, 4, 3-23.

Rivera-Uria, M.Y., Sedov, S., Solleiro-Rebolledo, E., Pérez-Pérez, J., McClung, E., González, A., Gama-Castro, J., 2007, Degradación ambiental en el valle de Teotihuacan: evidencias geológicas y paleopedológicas: Boletín de la Sociedad Geológica Mexicana, 59, 203-221.

Rojas-Rabiela, T., 1988, Las siembras de Ayer: La agricultura indígena del Siglo XVI: México, Secretaría de Educación Pública, 230 p.

Sanders, W.T., 1965, The Cultural Ecology of the Teotihuacan Valley: Pennsylvania, Department of Sociology and Anthropology, Pennsylvania State University Press.

Solleiro-Rebolledo, E., Sedov, S., McClung de Tapia, E., Cabadas, H., Gama-Castro, J., Vallejo-Gómez, E., 2006, Spatial variability of environment change in the Teotihuacan Valley during the Late Quaternary: Paleopedological inferences: Quaternary International, 156-157, 13-31.

World Reference Base for Soil Resources (WRB), 2006, A framework for international classification, correlation and communication: World Soil Resources Reports 103. Food and Agricultural Organization of the United Nations, Rome, $128 \mathrm{p}$.

Manuscript received: October 22, 2010.

Corrected manuscript received: October 17, 2011.

Manuscript accepted: March 10, 2012. 